\title{
Numerical study of flow characteristics on wing airfoil eppler 562 with whitcomb winglet variations
}

\author{
Setyo Hariyadi S.P ${ }^{1,2,}{ }^{,}$, Sutardi ${ }^{2}$, Wawan Aries Widodo ${ }^{1}$, Muhammad Anis Mustaghfirin ${ }^{3}$, \\ Arifandi Rachmadiyan ${ }^{1}$ \\ ${ }^{1}$ Fluid Mechanic Laboratory, Mechanical Engineering Department, FTI, ITS, 60111 Surabaya, \\ Indonesia \\ ${ }^{2}$ Aviation Polytechnic of Surabaya, 60111 Surabaya, Indonesia \\ ${ }^{3}$ Shipbuilding Institute of Polytechnic, 60111 Surabaya, Indonesia
}

\begin{abstract}
Winglet is a tool used to improve the efficiency of aircraft and UAV performance by preventing fluid flow jump from lower surface to upper surface at wingtip. The addition of this winglet resulted in improved lift and reduction of drag force from the aircraft wing or UAV. From Whitcomb's research, it was found that the use of winglet on a full size airplane can increase fuel efficiency by $7 \%$. The research led to the idea of conducting research on fluid flow characteristics on the UAV wing with the Eppler 562 airfoil combined with the whitcomb winglet. This numerical study was conducted using the Computational Fluid Dynamics (CFD) method based on the advantages of using this simulation that can review the fluid flow in macroscopic way. This study is provide accurate fluid flow visualization results and can improve the performance of the wings when compared with wings without winglet (plain wing). Wing with the Eppler 562 airfoil combined with the whitcomb winglet results reduction in rotating motion that makes velocity components as opposed to lift.
\end{abstract}

\section{Introduction}

The limited wing length results in a three-dimensional flow occurring at the tip due to the pressure difference on the upper surface and the lower side of the wing. This flow resulted in the emergence of a vortex or so-called tip vortex. The tip vortex resulted in reduce of effective area and increased drag coefficient on the aircraft. One solution to overcome tip vortex is to use a winglet.

Weirman (2010) conducted research in the form of numerical simulations and experiments on the performance of Whitcomb winglet and blended winglet on UAV. The simulation is done using open foam software that is Matlab with Vortex Lattice Method (VLM). This research aims to calculate the aerodynamic properties of winglet geometry

\footnotetext{
*Corresponding author: hudzaifahsetyo@gmail.com
} 
and choose optimum winglet design for its use in UAV. Weirman's research yielded the conclusions of improving lift coefficient $\left(C_{L}\right)$ on whitcomb winglet and blended winglet, and predicting increased aircraft resistance on winglets using winglets.

Research on the winglet is also done by Turanoğuz (2014) in the form of numerical simulations on UAV aircraft with the use of winglet on the wing of the aircraft. Turanoğuz uses three types of winglet in the form of hoerner winglet, shifted downstream winglet and blended winglet. The results obtained in this experiment in the form of a decrease in drag on the wing of the plane that uses the winglet compared with wings without winglet.

This research study of the fluid flow characteristics of the plane wing with the Eppler 562 airfoil type combined with the whitcomb winglet type winglet, where the angle of attack on the airfoil became a variable that could be varied. This numerical study was conducted using the Computational Fluid Dynamics (CFD) method based on the advantages of using this simulation that can review the fluid flow in macroscopic way. This study is provide accurate fluid flow visualization results and can improve the performance of the wings when compared with wings without winglet (plain wing). Increased performance is an increase in lift style and decrease drag force at the same angle of attack.

\section{Method}

\subsection{Model Speciment}

Numerical research was performed using Computational Fluid Dynamics (CFD) method with Ansys 17 to create wing geometry in the form of Eppler 562 airfoil with additional whitcomb winglet on wingtip. The choice of the Eppler 562 airfoil is based on a study of Turanoğuz (2014) with additional whitcomb winglet. Freestream velocity used at $10 \mathrm{~m} / \mathrm{s}$ and at $\alpha=0^{\circ}, 2^{\circ}, 4^{\circ}, 6^{\circ}, 8^{\circ}, 10^{\circ}, 12^{\circ}, 15^{\circ}, 17^{\circ}$ and $19^{\circ}$. Model speciment form airfoil E562 with winglets mounted on the tip shaped in Figure 1.

\subsection{Grid Independency}

Simulation software requires optimum grid and meshing in post processing steps and preprocessing. Grid independence needed to determine the extent and structure of the grid so that the best and most efficient model results closer to the experiment. Grid Independence, is a method for determining the optimum point of an experimental value. It should be understood that the use of the number of elements in numerical modeling affects the results. The more elements the more accurate the results but the running time becomes longer. The optimum point is the point where the result indicates the accuracy with the minimum number of elements possible. In addition, other considerations are based on Anderson (1995), the most optimal results obtained when the drag coefficient drill with meshing previously approximately $2 \%$.

The distribution of the number of meshing into 4 types, and then on the type of meshing will be sought magnitude of the smallest value of each meshing by comparing graphs numerical $C_{D}$ and $y^{+} . C_{D}$ and $y^{+}$values of grid independency are shown in Table 1 . Table 1. displays a meshing variation of the grid independence 3-D test model on Reynolds number $2.3 \times 10^{4}$. Determination of boundary conditions was adjusted to the research of Mulvany (2004) on flow through hydrofoil as shown in Figure 2.

The type and properties of the material accordance conditions of the environment at a temperature of $30^{\circ} \mathrm{C}$ and a pressure of $1 \mathrm{~atm}$. This model uses air as the working fluid $(\rho)=$ $1.17 \mathrm{~kg} / \mathrm{m}^{3}$, viscosity $(\mu)=1.86 \times 10^{-5} \mathrm{~N} . \mathrm{s} / \mathrm{m}^{2}$. The intensity of the turbulence on the numerical modeling is $0.8 \%$ and the length scale in the inlet side of $0,024 \mathrm{~m}$. Turbulence modeling used are viscous turbulent k- $\omega$ SST. The solution uses second order for the 
pressure, momentum turbulent kinetic energy and turbulent dissipation rate. Convergence criteria set at $10^{-5}$.
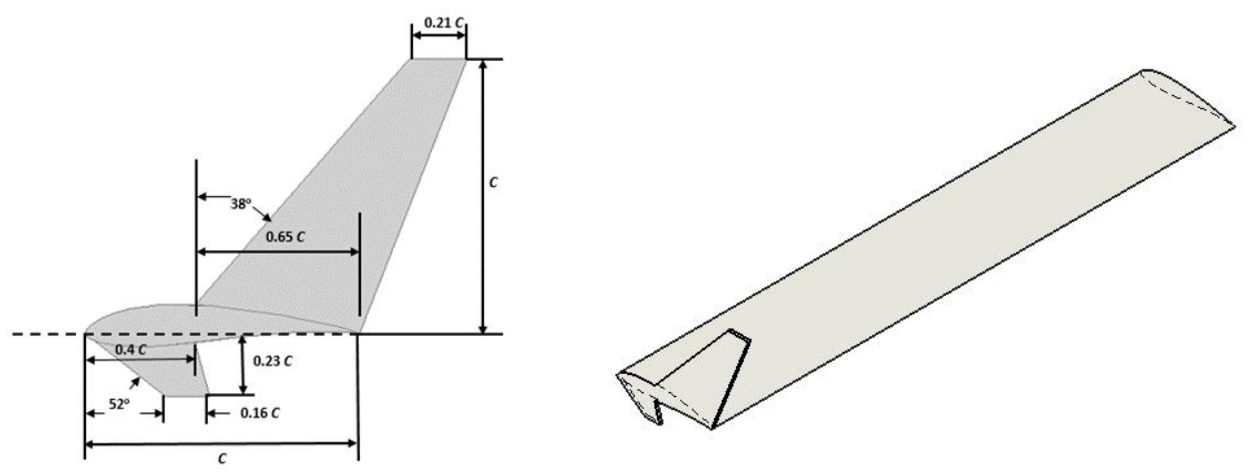

Fig. 1. Dimension of whitcomb winglet (Whitcomb, 1976)

Table 1. Grid analysis of independence model E562 3 dimensions without winglet.

\begin{tabular}{|c|c|c|c|c|}
\hline Type Meshing & Number of Cells & $\begin{array}{c}\text { Inflation } \\
\text { Layer }\end{array}$ & $C_{D}$ & $\mathrm{y}^{+}$ \\
\hline Meshing A & 469.682 & 40 & 0,86 & 2,1 \\
\hline Meshing B & 768.081 & 40 & 0,88 & 1,4 \\
\hline Meshing C & 569.313 & 40 & 0,90 & 0,8 \\
\hline Meshing D & 353.120 & 40 & 0,92 & 2,1 \\
\hline Meshing E & 335.582 & 40 & 0,93 & 2,8 \\
\hline
\end{tabular}

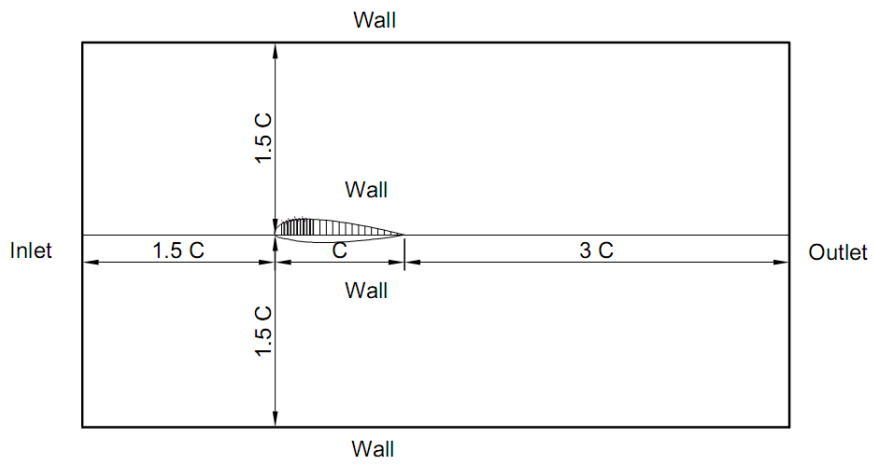

Fig 2. Modeling dimensions [5]

Meshing used in this research is hybrid mesh method and provides additional inflation layer in the area around the airfoil to analyze the boundary layer on the airfoil as shown in Figure 3. Meshing used is unstructured mesh with automatic method. Grading meshing is done in a vertical direction with mesh distribution getting tighter on all walls, either diverging wall or straight wall. This is done as the effect of the wall function.

In this research, to get the best result then $y+$ used is less than 1 as done in Kontogiannis research (2016). Based on Table 1. $C_{D}$ values tend to be smaller in Meshing C. One of the considerations in performing numerical simulation is the time and memory used, then the meshing used for the next simulation is Meshing C. 


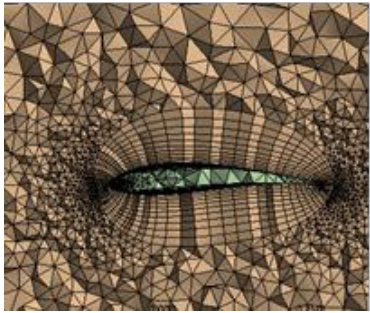

(a)

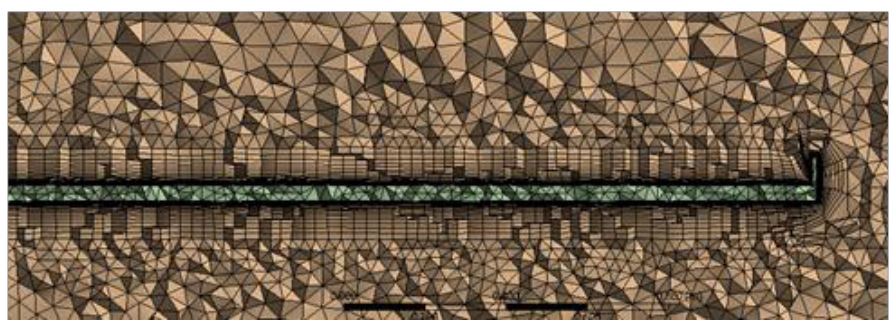

(b)

Fig. 3. Meshing and Domain Modeling Airfoil 3D with inflation layer with (a) meshing cross section at $\mathrm{z} / 1=0,5$ and (b) meshing cross section at $20 \%$ chord

\section{Results and Discussion}

\subsection{Velocity Pathline}

Figure 4 shows the velocity contour along with the pathline of the stream passing through the airfoil Eppler 562 without winglet and with the whitcomb winglet. At $\alpha=12^{\circ}$, and $\alpha=$ $15^{\circ}$, it can be seen that from the cut at the midspan and $5 \%$ of the tip $(\mathrm{z} / 1=0.95)$, the contours of velocity and pathline in each variation indicate a certain pattern.

At the angle of $\alpha=12^{\circ}$, there is a difference in the flow phenomenon across the airfoil midspan. In Eppler 562 airfoil with whitcomb winglet the wake phenomenon occurs larger than the Eppler 562 airfoil without the winglet. This phenomenon leads to an increase in drag force on Eppler 562 airfoil with whitcomb winglet. It is also happens at $\alpha=15$. But in the area near the tip $(\mathrm{z} / 1=0.95)$, it can be seen that the wing airfoil Eppler 562 with whitcomb winglet has a greater speed. This is due to the pressure on the upper surface of the Eppler 562 airfoil with the winglet whitcomb is smaller than whithout winglet. So that on the Eppler 562 airfoil with whitcomb the winglet has a higher velocity value on its upper surface.

\subsection{Velocity Pathline Structure}

Figure 5 (a) is a visualization of a velocity pathline on an plain wing with $\alpha=17^{\circ}$ and $\alpha=$ $19^{\circ}$. The visualization of the pathline shows that the flow on the midspan is distributed evenly across the span and tends to follow the contour of the body from leading edge up to its trailing edge. The pathline at the wingtip shows the fluid leaps from the lower to the upper surface and then combines with the flow from the leading edge. The combination of the two streams causes a rotating motion from leading edge to the trailing edge. As the $\alpha$ increases, the width of the rotating motion is wider as shown in Figure 5 (b). The rotating motion has downward velocity component or to the wing area which is often referred to as downwash velocity.

Figure 5 (c) shows the wing with the addition of whitchomb winglet at $\alpha=17^{\circ}$. At the midspan, fluid flow follows the surface of the wing body. For wing with whitchomb winglet, the airflow leaps from the lower surface can not be avoided in the leading edge area so the flow at the wingtip is little disturbed and can not follow the wing surface up to 
the trailing edge. The rotating motion that is formed is not perfect as it happens in plain wing. As the angle of attack increases to $\alpha=19^{\circ}$ (Figure 5 (d)), the fluid flow in the midspan can follow the surface area of the wing. The fluid flow near the wingtip can not follow the wing surface because there is leak of the airflow from the lower surface to upper surface.
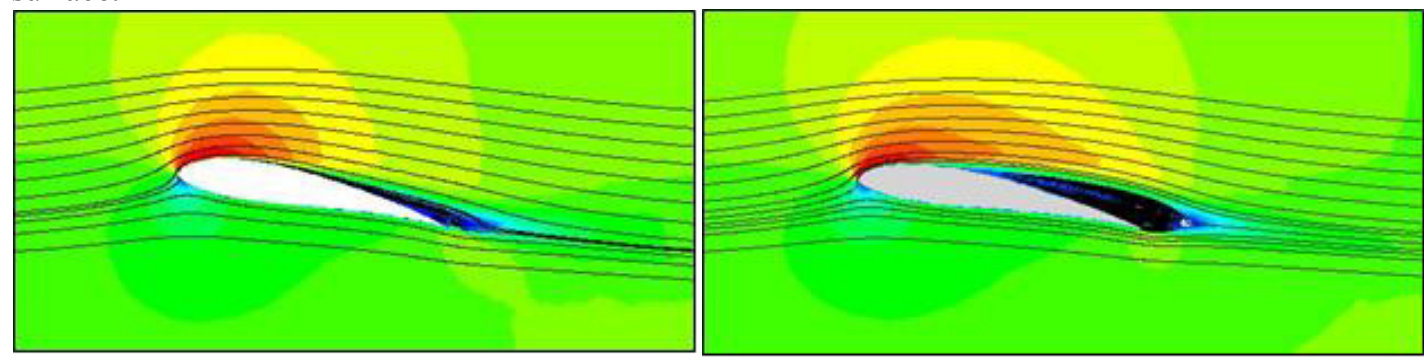

(a) Plain Airfoil $\alpha=12, z / l=0,5$

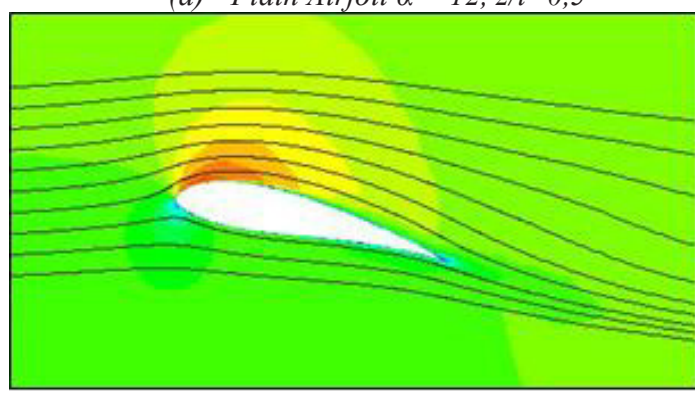

(c) Plain Airfoil $\alpha=12, z / l=0,95$

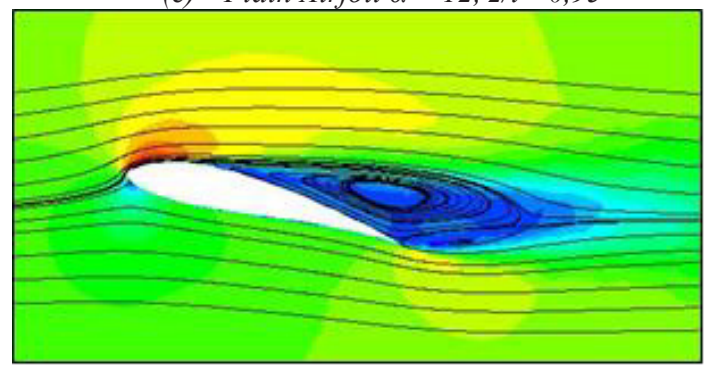

(e) Plain Airfoil $\alpha=15, z / l=0,5$

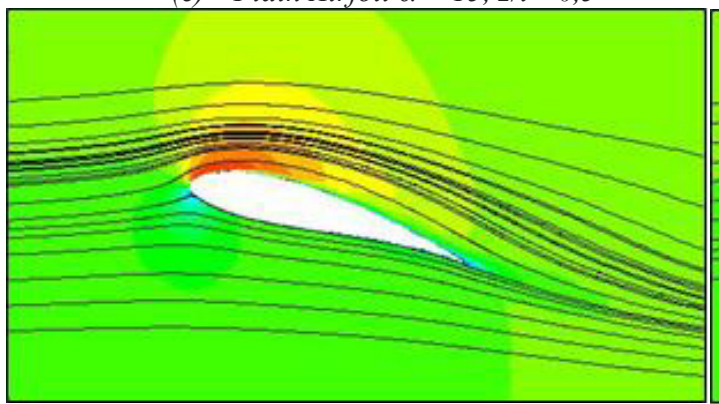

(g) Plain Airfoil $\alpha=15, z / l=0,95$ (b) Whitcomb Winglet $\alpha=12, z / l=0,5$

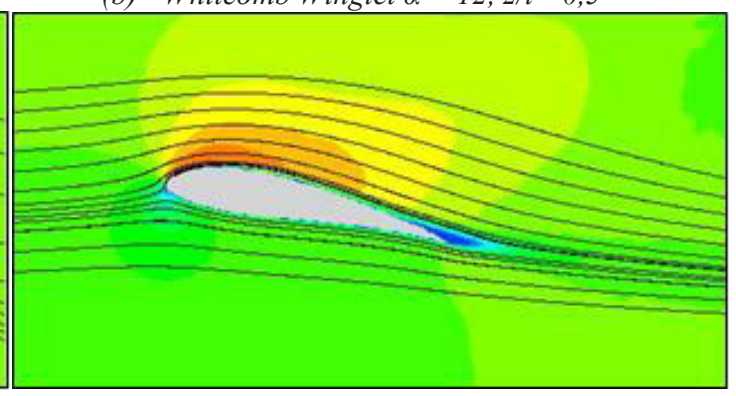

(d) Whitcomb Winglet $\alpha=12, z / l=0,95$

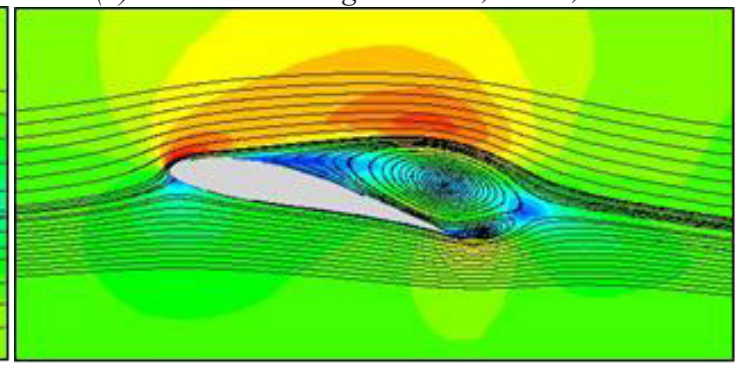

(f) Whitcomb Winglet $\alpha=15, z / l=0,5$

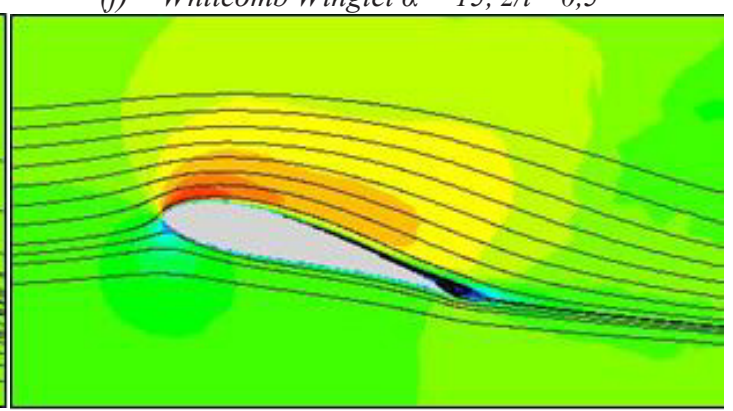

(h) Whitcomb Winglet $\alpha=15, z / l=0,95$ 


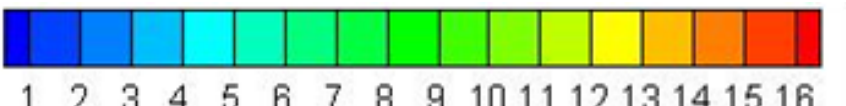

Fig. 4. Velocity Contour and Velocity Pathline at midspan and near wingtip airfoil Eppler 562

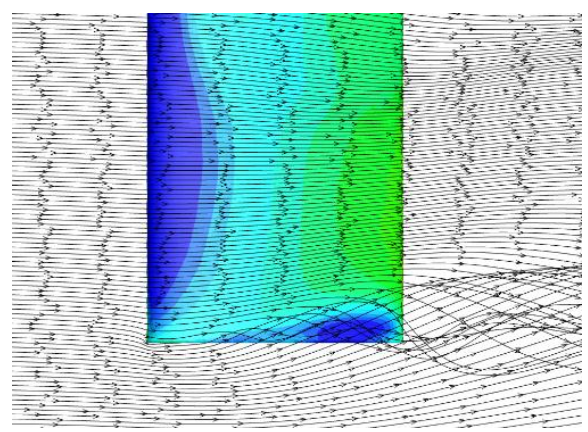

(a) Plain Wing $\alpha=17^{\circ}$

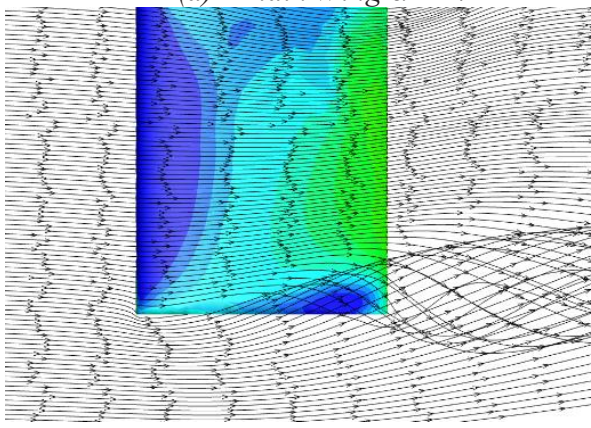

(b) Plain Wing $\alpha=19^{\circ}$

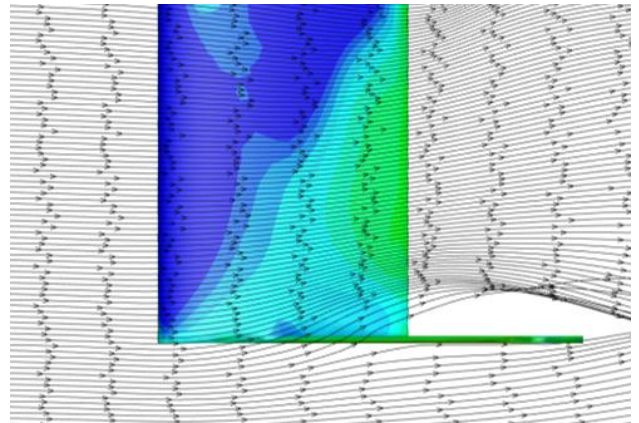

(c) Whitcomb Winglet $\alpha=17^{\circ}$

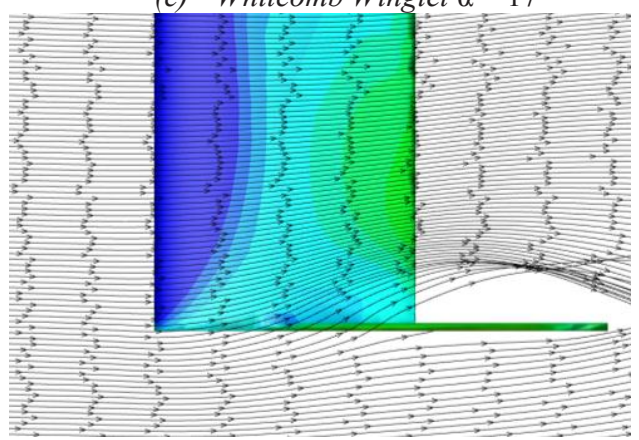

(d) Whitcomb Winglet $\alpha=19^{\circ}$

Fig. 5. Velocity Pathline Structure of the plain wing and whitchomb winglet at $\alpha=17^{\circ}$ and $19^{\circ}$

\section{Conclusion}

The result of this study show that use whitchomb winglet can improve the performance of the wing even with the addition of whitchomb winglet cannot be avoided rotating motion. The rotating motion is caused by combination of the two streams from leading edge to the trailing edge. The rotating motion that is formed is not perfect as it happens in plain wing.

At the area near the tip $(z / l=0.95)$, wing airfoil Eppler 562 with whitcomb winglet has a greater speed. This is due to the pressure on the upper surface of the Eppler 562 airfoil with the winglet whitcomb is smaller than whithout winglet. So that on the Eppler 562 airfoil with whitcomb the winglet has a higher velocity value on its upper surface.

\section{References}

1. Weirman, Jacob, D. Jamey. Winglet Design and Optimization for UAVs, Chicago, USA, $28^{\text {th }}$ AIAA Applied Aerodynamics Conference (2010)

2. Turanoğuz, Eren, Thesis, Aerospace Engineering Department, Middle East Technical University Turkey (2014)

3. J. D. Anderson. Mc-Graw Hill. New York (1995) 
4. Whitcomb, T. Richard T. Washington D.C., USA. National Aerospace and Space Administration (1976)

5. Mulvany, J. Nicholas, L. Chen, Y. T. Jiyuan and B. Anderson. Final Report, Defence Science and Technology Organisation, Departement of Defence, Australian Goverment (2004)

6. S.G Kontogiannis, D. E. Mazarakos and V. Kostopoulos, Science Direct : Aerospace Science and Technology (2016) 